\title{
TERF1 wt Allele
}

National Cancer Institute

\section{Source}

National Cancer Institute. TERF1 wt Allele. NCI Thesaurus. Code C52493.

Human TERF1 wild-type allele is located in the vicinity of $8 \mathrm{q} 13$ and is approximately $39 \mathrm{~kb}$ in length. This allele, which encodes telomeric repeat-binding factor 1 protein, is involved in the attenuation of telomere extension. 